\title{
Effect of Billboard/Poster Advertising on Consumer Patronage of Home Video in Awka Metropolis, Anambra State
}

\author{
Christiana Obiageli Igwe Ireneus C. Nwaizugbo* \\ Department of Marketing, Nnamdi Azikiwe University, Awka
}

\begin{abstract}
This study examined the effects of Billboard/Poster advertising and consumer patronage of home videos in Awka. The study focused on determining the effects of the dimensions of location, content, size and model of Billboard/Poster advertising on consumer patronage of home-videos in Awka. In order to achieve this objective, a descriptive research design was adopted with survey as a method for collecting primary data. The population of the study comprises students of Nnamdi Azikiwe University, Awka Campus. Accordingly, sample size of 395 respondents was statistically determined as adequate from the population of 33,400 students using Taro Yamane's formula. Stratified random sampling was adopted and research instrument was structured questionnaire. The reliability of the research instrument was tested using Factor analysis. Results were presented in tables and hypotheses were tested using Multiple Linear Regressions (MLR). The result of the study revealed that location and contents of billboards/posters have significant positive relationship on consumers' patronage of home videos. It was also found out that sizes and models have positive effect but no significant relationship with consumer patronage of home-video. In conclusion billboards/poster remains effective tool of outdoor advertising.
\end{abstract}

Keywords: Billboard/Poster Advertising, Consumer Patronage, Home Videos, Advertising Media

DOI: $10.7176 / \mathrm{EJBM} / 12-36-06$

Publication date: December $31^{\text {st }} 2020$

\subsection{Background of the Study}

The need to promote products in order to gain patronage in the market cannot be over emphasized, especially in the current environment of intensive competition. Advertising has always played a catalyst role in creating awareness for the product and persuading the customers to desire and adopt the product as a valued solution to their needs. Advertising is defined as a non - personal communication of information that is paid for and usually persuasive about producer by an identified sponsor through various media (Nwaizugbo, 2004). Advertising therefore is one of the marketing communication tools that ensure the survival of any business because development and growth of business depends on communication of the product information to the target audience. Present day market environment, especially with the in technology, has witnessed the presence of multiple advertising media through which lots of information is bombarded to the target audience. This notwithstanding billboard advertising medium remains relevant. Billboard advertising medium has a special character of using the spacious surface provided by the medium to creatively present well designed pictures and boldly printed words to attract the attention of highly mobile audience in the cities to the product they promote. People are so much engaged in many activities, as such spend most of their time outside their homes, and this makes them have little or no time to update themselves with necessary business information. In view of this, whatever they are exposed to during the hustling of the day captures their attention, centers on their sub-consciousness and influences their purchase decisions (Mustapha, Karaca \& Kitapci, 2010).

Many firms choose different advertising media to attract customer's attention to their products. Movie industry and their marketers use outdoor/poster advertising as one of the major tools to attract customers to their products and services. Billboards/Posters write-up are few words with large- prints, it uses bright colored text and images. Billboards /Posters advertising are eye-catching and it is relatively long lasting when compared to other advertising media. It creates awareness rapidly with its short and simple slogans readable at a glance. Billboards/posters are designed to catch attention of audience on the move and create memorable impression sharply in the customers mind. (Abideen \& Saleem, 2011;Katke, 2007).

\subsection{Statement of the Problems}

Billboards/posters are outdoor channels for communicating to a large audience publicly. Since the nineteenth century, billboards have continued to compete as a top advertising channel, with such a life span, there is something convincing about billboards/posters that attracts consumer's eye for a few seconds (Williams, 2004). According to the Outdoor Advertising Association of America (2015), billboards stretch the boundaries of creativity to heighten advertisement awareness and grab consumers' attention. With the surge in the number of media options available to advertisers, it is not known whether billboard/poster retain its position of pride in the ranking of advertising media.

However due to the rise in technology and increasing globalization where consumers are expose to information on the internet, billboards and posters are gradually becoming Questionable, there is need to ascertain 
whether this medium of advertising channel (billboards/posters) is still relevant for promoting home videos successfully.

The effectiveness of billboard/poster as advertising medium depends on the strategic mix of the dimensions. The dimensions of billboard/poster include location, content, size and model. Studies have agreed that these features contribute to the effectiveness of billboard/poster but none of the studies explain the effectiveness of the features as it relates to Home Video advertising.

Posters when placed compete for space in the same location, different product posters, political posters, church posters, obituary posters and home video posters compete for space, there is need to ascertain if posters still attract consumers' patronage to home videos.

Several studies have been conducted on billboards/posters. Most of these studies focused on product such as Home Appliances, Cosmetics, Telecommunication, Beverages and Brewery. There is a scarcity in literature on home videos; this study therefore seeks to examine the effect of billboards/posters advertising on consumers' patronage of home video.

\subsection{Objectives of the Study}

The broad objective of the study is to determine the effect of billboard/posters advertising on consumer's patronage of home videos in Awka, Anambra State. Specific objectives of the study are to ascertain the effects of billboard/poster locations, size, content and model on consumers' patronage of home videos in Awka Metropolis. Research questions are set up accordingly to drive the study as follows:

i. What is the relationship between billboard/poster locations and consumers' patronage home videos?

ii. What is the relationship between billboard/poster size and consumers' patronage home videos?

iii. What is the relationship between billboard/poster contents and consumers' patronage of home videos?

iv. What is the relationship between billboard/poster model and consumers' patronage of home videos?

\subsection{Determinants of Outdoor Advertising}

\section{Billboard/Poster Location and consumer patronage}

The location of advertising is a significant factor in both the probability and frequency of audience exposure. Unlike other forms of display advertising (newspapers, magazines, internet banner advertising etc.), a large proportion of the audience for outdoor advertising materials do not have control over their length of exposure. Location of billboards/posters advertising means that it needs to be properly placed in a strategic site according to the advertisers target market (Taylor, Franke \& Bang, 2006). Location of billboard influences buying decision because it targets the audience which advertisers really want to convey their message to. Through billboard advertising, advertising practitioners can directly target the customers that they really want to hit at in any geographical location. Advertising practitioners and marketers want to select the appropriate location where they can target maximum people at a time (Taylor, Franke \& Bang, 2006). Without selecting appropriate location it will be difficult for the advertisers to deliver their target message to the target customers. If billboards are wrongly placed or located, then they are not likely to draw the maximum attention of the target market as needed. Hypothesis one is therefore presented as follows:

HO1: Billboard/Posters location has no significant positive relationship with consumer patronage of home video in Awka Metropolis.

\section{Billboard/poster Size}

Size of the billboards/posters explains how large and small the size of billboard in the form of height and width. According to Shimizu, (2002) large haul billboards of big brands like Coca cola, Pepsi and other popular beverages grabs the direct attention of consumers. It directly relates the brand's popularity. Normal and small size billboards/posters usually represents sophisticated brands and used by the companies that recently launched their brand and wants to draw attention to the consumers to their products. As far as size of a billboard is concerned, it is generalized into two general groups large and small in the form of height and width. Sizes matters a lot in brand awareness. For example, big size may not make brand awareness always, whereas small size and larger quantity may make a better brand awareness. Some marketers with a vague concept only go for larger billboards. This can result in lesser number all over the targeted area. Whereas some smart marketers play with visibility of brand in maximum places and work on small sizes and more placement. It can now reach maximum reach and frequency in a nominal cost and in a very best way, whereas size is also dependent on a brand. Hypothesis two, therefore is presented accordingly:

$\mathrm{HO}_{2}$ : Billboard/poster size has no significant positive relationship with consumers' patronage of home video in Awka Metropolis.

\section{Billboard/Poster Content}

Message content is another factor which influences buying behavior of the customers. If advertisers really want to convey their message to the target audience, then it is necessary that information that is display on billboard is relevant, obvious, understandable and appealing (Willson, 2015).Content of billboard explains the imagery, text, 
color, graphics and visuals used in billboards/posters. It also represents the level of brand awareness, for instance if the brand is recently launched they use more description and less images to introduce the brand.

According to Eva, Chelo and Rutherford (2013), contents must be set according to your target audience like languages and images must be selected in a manner that it can suit your audience and describe your product at a glance. Messages must be clear, short and simple in contents, because audiences who will read the billboard have less time to read the long detailed content on a billboard. Since motion audience don't have much time to read and stare at the billboards. Brands must put a short content that can be quickly understood so that customers can get immediate recall and recognition even at a single glance. If this is done correctly, then it is most likely to have effect consumers' patronage. Accordingly, hypothesis three is presented as follows:

$\mathrm{HO}_{3}$ : Billboard/poster content has no significant positive relationship with consumers' patronage of home video in Awka Metropolis.

\section{Billboard/Poster Models}

Model is a person employed to display, advertise and promote a commercial product, notably fashion (clothing), Cosmetics, Make-ups. Most often Celebrities and Artist are used. In advertising, the use of attractive models is believed to be effective in increasing sales. Ad News (2006) in a study reveals that physical attractiveness of models has tremendous effect on how men and women see, evaluate and purchase certain products. It asserted that use of Models in Billboard advertising is to draw audience attention. In contemporary Nigerian society, the use of models has been predominant and widespread in outdoor advertising, billboards/posters advertising which has brought tremendous change especially on sales of products. Belch \& Belch, (2001) asserted that companies spend huge sums of money to have models appear in their advertising. This is because of its attractive force in drawing attention of the audience to a product, sustaining their interest and giving the product a personality.

However, Bower (2011) notes that "attractive models could increase and sometime decrease advertising effectiveness because it deflates the self-image of potential customers when they compare themselves to these models. Richins (1995) reported that when sufficient negative effect is generated as a consequence of comparison with beautiful models, evaluation of both the model as a spokesperson and the product may be affected adversely, because of model derogation. The comparison with these beautiful models may lead to negative feelings such as frustration and anxiety. Nevertheless, models in Billboard/poster adverts have effect on consumer patronage, hence hypothesis four:

$\mathrm{HO}_{4}$ : Billboard/poster model has no significant positive relationship with consumers' patronage of home video in Awka Metropolis.

\subsection{Challenges of Billboard/Posters Advertising}

Despite all these roles outdoor advertising play in product awareness, Perreault and McCarthy (2003) reported that outdoor advertising alone cannot convince a consumer to patronize a product or service contrary to his choice and brand. Critiques argue that sometime the write ups are ambiguous and offensive, thereby distracting the public. Richin (1995) and Bower (2011) also argues that the use of very attractive models and half nude pictures in billboards/posters advertising sometimes creates distractions as audiences focus their attention on the models rather than the products advertised.

Another challenge of billboard /posters advertising is site monitoring, Monitoring of billboard/poster sites are usually difficult due to the distance, and some of them are mounted at different far locations, so when the posters are torn by breeze or washed out sometimes fades dues to excessive sun. It takes longer time to discover it by the advertisers and report for necessary repairs because those sites are far and scattered (Ozoh, 1998).

The billboards/posters advertising most of the time compete for space, Product advertising posters are competing with political posters, obituary posters and Church posters thereby causing obstructions everywhere. Finance is also a source of challenge to outdoor advertising, for a sizable billboard to be put in place it cost a whole lot of money and to print a good poster to attract public attention also cost a lot of money.

Another challenge of outdoor advertising according to Lichtenthal (2004) is producers presenting false evidence about the qualities of their products in advertising to get attention of the customers, some marketers' raises the (USP) unique selling preposition of a product, rates their products higher than its real value during advertising.

\subsection{Methodology}

Survey research design was adopted for the study. The area of this study was Awka Metropolis of Anambra State. The population of the study comprises of students of Nnamdi Azikiwe University, Awka Campus. A sample size of 395 respondents was statistically drawn out from the population size of 33,400 students using Taro Yamane's formula. Stratified random sampling was adopted and research instrument was structured questionnaire. Students were used for the study because young are mostly strong influencers in entertainment consumption in the family. Multiple choice 5-point likert scale questionnaire was used to the requisite data. The instrument was tested reliability using Factor analysis and for validity using face validation. . Hypotheses were tested using Multiple 
Linear Regressions (MLR). The data obtained was analyzed using the software, Statistical Package for Social Sciences (SPSS). The mathematical model for study was:

$$
\mathrm{Y}=\mathrm{a}+\beta \mathrm{x}_{1}+\beta \mathrm{x}_{2}+\beta_{\mathrm{x} 3}+\beta_{\mathrm{x} 4}+\mathrm{e}_{\mathrm{i}}
$$

Where:

$\mathrm{Y}=$ Dependent variable (consumer patronage)

$\mathrm{a}=$ intercept or constant

$\beta=$ coefficient associated with the independent variables

$\mathrm{X}_{1}, \mathrm{x}_{2}, \mathrm{x}_{3}, \mathrm{x}_{4}=$ independent variables (Billboard location, billboard size, Message content, billboard models).

\subsection{Data Presentation and Hypotheses testing}

A total of 395 copies of questionnaire were distributed to the respondents and 306 copies were retrieved while only 278 copies were used for the study after faulty ones were discarded. The results arising from the response of the respondents to the questions as contained in the questionnaire are presented below.

Table 4.1: Responses to the Billboard/poster location items

\begin{tabular}{|c|c|c|c|c|c|c|}
\hline Billboard/Poster location and Consumer Patronage & 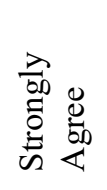 & 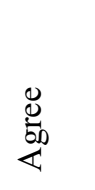 & $\begin{array}{l}\bar{\pi} \\
\stackrel{\Xi}{\Xi} \\
0 \\
Z\end{array}$ & 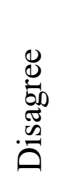 & 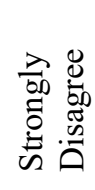 & \\
\hline $\begin{array}{l}\text { Movie billboard and posters located in a busy area attract } \\
\text { maximum attention of the consumers to the product }\end{array}$ & 92 & 146 & 24 & 10 & 6 & \\
\hline $\begin{array}{l}\text { Billboards/Posters placed on a good site stimulateconsumers' } \\
\text { interest to purchase the home video. }\end{array}$ & 68 & 140 & 46 & 24 & - & \\
\hline $\begin{array}{l}\text { Billboards/posters located properly, stirs up a desire inside the } \\
\text { consumer to patronize the home video. }\end{array}$ & 88 & 128 & 46 & 10 & 6 & \\
\hline $\begin{array}{l}\text { Billboards/posters located along busy roads is a huge } \\
\text { distraction to me and other passers bye }\end{array}$ & 108 & 100 & 44 & 26 & - & \\
\hline Average & 89 & 128.5 & 40 & 17.5 & 3 & 4.02 \\
\hline
\end{tabular}

Source: Field Survey, 2019

In table 4.1, $238(85.6 \%)$ respondents were in agreement to statement 1, $24(8.6 \%)$ were neutral, while 16 $(5.8 \%)$ disagreed to the statement. In statement 2, $208(74.9 \%)$ respondents agreed to the statement, $46(16.5 \%)$ were neutral while $24(8.6 \%)$ disagreed to statement 2 . The table also showed that $216(77.7 \%)$ of the respondents agreed in statement 3, $46(16.5 \%)$ were neutral while $16(5.8 \%)$ respondents disagreed. In statement 4, $208(74.8 \%)$ of the respondents were in agreement to statement $4,44(15.8 \%)$ were neutral while $26(9.4 \%)$ disagreed. The mean score for the variable of location is 4.02 .

Table 4.2: Responses to Billboard/Poster Size items

Billboard/Poster size and consumer patronage

\begin{tabular}{|l|l|l|l|l|l|l|}
\hline Billboard/Poster size and consumer patronage & & & & & \\
& & & & & \\
& & & & \\
\hline $\begin{array}{l}\text { Large size Billboard/posters is eyes catching and draws attention } \\
\text { of the pedestrians to the product. }\end{array}$ & 162 & 80 & 28 & 8 & - & \\
\hline $\begin{array}{l}\text { Large size of billboard/poster helps in creating brand awareness to } \\
\text { consumers. }\end{array}$ & 96 & 120 & 44 & 16 & 2 & \\
\hline Big size billboard/posters make a message readable at a glance. & 116 & 100 & 30 & 28 & 4 & \\
\hline $\begin{array}{l}\text { Large size of billboard/poster makes them to stand out from its } \\
\text { surrounding, thereby creating desire on the consumers mind. }\end{array}$ & 112 & 118 & 26 & 22 & - & \\
\hline Average & 121.5 & 104.5 & 32 & 18.5 & 1.5 & 4.17 \\
\hline
\end{tabular}

Source: Field survey, 2019

In table $4.2,242(87.1 \%)$ respondents were in agreement to statement $1,28(10.1 \%)$ were neutral, while 8 $(2.9 \%)$ disagreed to the statement. In statement 2, $216(77.7 \%)$ respondents agreed to the statement, $44(15.8 \%)$ were neutral while $18(12.8 \%)$ disagreed to statement 2 . The table also showed that $216(77.7 \%)$ of the respondents agreed in statement 3, $30(10.8 \%)$ were neutral while $32(11.5 \%)$ respondents disagreed. In statement 4, $230(42.7 \%)$ of the respondents were in agreement to statement $4,26(9.4 \%)$ were neutral while $22(7.9 \%)$ disagreed. The mean score for the variable of size is 4.17 . 
Table 4.3: Responses to Billboard/Poster Content items

\begin{tabular}{|c|c|c|c|c|c|c|}
\hline Billboard/Poster content and consumer patronage & 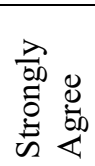 & 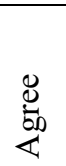 & $\begin{array}{l}\bar{\pi} \\
\stackrel{\Xi}{0} \\
\overline{0}\end{array}$ & $\begin{array}{l}8 \\
\stackrel{d}{0} \\
\stackrel{\mathscr{D}}{0} \\
\ddot{0}\end{array}$ & 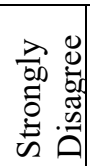 & \\
\hline $\begin{array}{l}\text { The colours and pictures of Billboard/postersadvertising spur my } \\
\text { purchase intention of home videos. }\end{array}$ & 78 & 126 & 54 & 10 & 10 & \\
\hline $\begin{array}{l}\text { Messages on the billboard appealing and eyes catching, it attracts } \\
\text { consumers' interest to the home video. }\end{array}$ & 46 & 136 & 74 & 18 & 4 & \\
\hline $\begin{array}{l}\text { Short and sharp messages of most home video posters stimulate an } \\
\text { interest in me to make purchases. }\end{array}$ & 80 & 104 & 64 & 28 & 2 & \\
\hline $\begin{array}{l}\text { Massages on billboard should not be offensive, ambiguous or } \\
\text { abusive }\end{array}$ & 124 & 102 & 28 & 10 & 14 & \\
\hline Average & 82 & 117 & 55 & 16.5 & 7.5 & 3.90 \\
\hline
\end{tabular}

Source: Field Survey, 2019

In table 4.3, $204(73.4 \%)$ respondents were in agreement to statement 1, $54(19.4 \%)$ were neutral, while 20 (4.2\%) disagreed to the statement. In statement 2, $182(66.2 \%)$ respondents agreed to the statement, $74(26.6 \%)$ were neutral while $22(7.9 \%)$ disagreed to statement 2 . The table also showed that $184(66.2 \%)$ of the respondents agreed in statement 3, $64(23.0 \%)$ were neutral while $30(17.1 \%)$ respondents disagreed. In statement 4, 226 (81.3\%) of the respondents were in agreement to statement 4, $28(10.1 \%)$ were neutral while $24(8.6 \%)$ disagreed. The mean score for this variable of content is 3,90 .

Table 4.4: Responses on Billboard/Poster Models items

\begin{tabular}{|c|c|c|c|c|c|c|}
\hline Billboard/Poster model and consumer patronage & 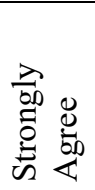 & $\begin{array}{l}\stackrel{8}{\infty} \\
\stackrel{5}{4}\end{array}$ & $\begin{array}{l}\bar{\pi} \\
\stackrel{\Xi}{0} \\
\overline{0}\end{array}$ & 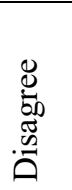 & 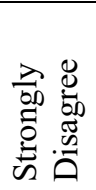 & \\
\hline $\begin{array}{l}\text { Most home video models are quite attractive and eye catching to } \\
\text { me }\end{array}$ & 80 & 126 & 46 & 20 & 6 & \\
\hline Attractive models draw my attention to the release of a new movie & 86 & 148 & 26 & 12 & 6 & \\
\hline $\begin{array}{l}\text { Nollywood celebrity models are more important to the audience } \\
\text { than the title of the movie }\end{array}$ & 54 & 110 & 62 & 46 & 6 & \\
\hline $\begin{array}{l}\text { Female models attract audience attention to themselves more than } \\
\text { the products they are advertising. }\end{array}$ & 58 & 122 & 58 & 32 & 8 & \\
\hline Average & 69.5 & 126.5 & 48 & 27.5 & 6.5 & 3.8 \\
\hline
\end{tabular}

Source: Field Survey, 2019

In table 4.8, $206(74.1 \%)$ respondents were in agreement to statement 1, $46(16.5 \%)$ were neutral, while 46 $(16.5 \%)$ disagreed to the statement. In statement 2, $234(84.1 \%)$ respondents agreed to the statement, $26(9.4 \%)$ were neutral while $18(6.5 \%)$ disagreed to statement 2 . The table also showed that $164(59 \%)$ of the respondents agreed in statement 3, $62(22.3 \%)$ were neutral while $52(18.7 \%)$ respondents disagreed. In statement $4,180(64.8 \%)$ of the respondents were in agreement to statement 4, $58(20.9 \%)$ were neutral while $40(24.4 \%)$ disagreed. The mean score for the variable of model is 3.8 .

Testing of Hypotheses

Multiple linear regression (MLR) was used to analyze the data and test our hypotheses. The results of the analyses are as shown below. Further result shows that the four independent variables only accounted for $13.36 \%$ of the predicted variations (R-squared (pred.). Variance inflation factor (VIF) which tests co-linearity shows that all the VIF values are below the threshold of 5 showing further that there is absence of co-linearity.

Table 4.5: Multiple Linear Regression Output

\begin{tabular}{|c|c|c|c|c|c|c|c|}
\hline \multirow{2}{*}{\multicolumn{2}{|c|}{ Model }} & \multicolumn{2}{|c|}{ Unstandardized Coefficients } & \multirow{2}{*}{$\begin{array}{l}\text { Standardized } \\
\text { Coefficients } \\
\text { Beta } \\
\end{array}$} & \multirow[b]{2}{*}{$\mathrm{t}$} & \multirow[b]{2}{*}{ Sig. } & \multirow[b]{2}{*}{ VIF } \\
\hline & & $\mathrm{B}$ & Std. Error & & & & \\
\hline 1 & (Constant) & 3.361 & .689 & & 4.875 & .000 & \\
\hline & Billboard/Poster location & .242 & .064 & .249 & 3.779 & .000 & 1.464 \\
\hline & Billboard/Poster size & .049 & .067 & .046 & .730 & .466 & 1.330 \\
\hline & Billboard/Poster content & .256 & .056 & .264 & 4.532 & .000 & 1.145 \\
\hline & Billboard models & .010 & .058 & .010 & .180 & .857 & 1.128 \\
\hline
\end{tabular}

Billboard/poster location (BPL) has a positive coefficient of 0.2423 and a T-Value of 3.78. It also has a ` $\rho$ - 
Value of 0.000 which well below the $5 \%$ level of significance. Based on this we rejected null hypothesis one which states that:

HO1: there is no positive significant relationship between billboard/poster location and consumers' patronage.

The conclusion is that there is a positive significant relationship between billboard/poster location and consumers' patronage of home movie. This is in line with the study of Hussani and Nizamani (2011) on Factors affecting consumer attention in Billboard Advertising; his finding reveals that locations and contents of billboard creates awareness sharply and draws audience attention to the product advertising.

Billboard/poster size (BPS) has a positive coefficient of 0.0491 and a T-Value of 0.73 with a ` $\rho$-Value of 0.466 which well above the $5 \%$ level of significance. Based on this null hypothesis two which states that:

$\mathrm{HO} 2$ : there is no positive significant relationship between billboard/poster size and consumers' patronage is accepted.

The conclusion is that there is a positive but no significant relationship between billboard/poster size and consumers' patronage of home movie. This to an extent agrees with study of Shimizu (2002) who asserted that large billboards grabs direct attention of consumer and directly related to brand popularity, whereas small size billboards spread across a large area creates a better brands awareness. This opinion was endorsed by some respondents who comment that large sized billboard do not create any better impression than smaller ones that are positioned in multiple places.

Billboard/poster content (BPC) has a positive coefficient of 0.2560 and a T-Value of 4.53. It also has a ` $\rho$ Value of 0.000 which well below the 5 percent level of significance. Based on this we rejected null hypothesis three which states that:

HO3: there is no positive significant relationship between billboard/poster content and consumers' patronage.

The conclusion is that there is a positive significant relationship between billboard/poster location and consumers' patronage of home movie. This is in agreement with the study of Kamran (2016) on his study Billboard Advertising and Customer Attention, variables used in the study include colour, size, celebrity image, brand image logo, text and messages, the result reveals that these variables has a significant positive relationship with consumers' attention to a product.

Billboard/Poster model (BPM) has a positive coefficient of 0.0104 and a T-Value of 0.18 and a ` $\rho$-Value of 0.857 which well above the 5 percent level of significance. Based on this we accept null hypothesis four which states that:

HO4: there is no positive significant relationship between billboard/poster model and consumers' patronage.

The conclusion is that there is a positive but no significant relationship between billboard/poster location and consumers' patronage of home movie. This agrees with the study of Bower (2001) on 'Highly attractive models in Advertising'. His findings reveal that audience use to compare themselves with the models used in advertising the products. This shows that models are now shifting the audience attention to themselves rather than the products advertised.

\subsection{Summary of Findings}

1. Billboards/Posters location has a positive significant relationship with consumers' patronage of home videos, with the p-value of 0.000 which is less than 0.05 level of significance.

2. Billboards/posters size has a positive but no significant relationship with consumers' patronage of home video, with the $\mathrm{p}$-value of 0.466 which is well above the 0.05 level of significance.

3. Billboards/posters content has a positive significant relationship with consumers' patronage of home video, with the $\mathrm{p}$-value of 0.000 which is less than 0.05 level of significance.

4. Billboard/poster models have a positive but no significant relationship with consumers' patronage of home video, with the p-value of 0.857 which is well above the 0.05 level of significance.

\subsection{Conclusion}

This study examined billboards/posters advertising and consumers' patronage of home video, the study established that locations and the contents of the billboards/posters are very important factors to be considered in placement of billboards/posters. The study also established that sizes and models are positive but have no significant relationship to consumer patronage; therefore emphases should be laid on using smaller sizes of billboard but on larger and wider area. Then models that are directly related to the products should be used in advertising. Billboard and posters remains effective marketing tool for home video marketers, because of its vast reach, and its ability to draw attention rapidly which leads to patronage. 


\subsection{Recommendations}

In line with the findings of this study, recommendations were made as follows.

Since billboard/poster locations have positive relationship with consumer patronage of home videos, the researcher now recommends the more use of billboards/posters, at strategic position to draw audience attention to the product. The researcher also recommends more use of Electronic billboards, since it can attract commuters' attention day and night.

1. Producers and marketing practitioners of home video should be creative in drawing the contents of billboards/posters. They should make it sharper and short, with simple write-ups that will be attractive to draw consumers' attention.

2. The researcher also recommends that since large size billboard/poster creates direct attention and brand popularity but smaller sizes and large number of billboards/posters can be used to reach a vast audience, the research recommends smaller and vast number to be used.

\section{REFERENCES}

Abideen, Z. U. \& Saleem, S. (2011). Effective advertising and its influence on consumer buying behaviour. European Journal of Business and Management, 3(30), 55-56.

Balkafl, Akbulut\&Kartopu, (2005).An evaluative study of billboard advertisement attention-perceptio and design criterias; January.

Belch, M. A. \& Belch, G. (2001). Advertising and promotion: An integrated marketing communications perspective: Boston Macgraw-Hill, United State.

Bower, A. B. (2011). Highly attractive models in advertising and the women who log the them: implications of negative effect for spokes person effectiveness. Journal of Advertising, 3(3), 30-54.

Eva, B. F. \& Chelo B. A. (2013).Creativity in traditional outdoor advertising platforms in castellon.online. Journal of Communication and Media Technologies. 1(13), 2.

Katke, K. (2007). The impact of television on child health and family spending. International marketing conference on marketing and society. Retrieved from http//www.itu.int/itou/ict/newslog/content/binary/20-2008jpg.

Lichtental, Y. \& Donthu, O. (2006). Product attributes for business markets implications for selling and sales. Online library. Wiley.com $>$ doi $>$ abstract.

Lichtenthal, J., David, V. N., \& Naveen, D. (2006). Outdoor advertising for business market industrial marketing management, 3(5), 236-247.

Lichtenthal, Y. \& Donth, M. (2004). Policy makers foundation series in business marketing, lichtenthal J. D. Editor Best books imprint, Haworth Press.

Mccarthy, J. E. (2003). Drivers distraction by advertising. Genuine risk or urban Mythy New Jersey: prentice Hall.

Mustapha, G., Karaca, S. Kita, P. (2010). The effect of outdoor advertisement on consumers: A case study, studies in business and economics. http://www.reserachgate.net/publication/465/13458.

Mustapha, K. \&Kitapci, P. (2010). The effect of outdoor advertising on consumers: A case study: studies in business and economics. http://www.researchgate.netpublication /4051345

Okoro, N. (1998). The business of advertising. Enugu: Acena Publishers.

Ozoh, H. C. (1998). Principles and practice of advertising Lagos.NELAG.

Shimizu, K. (2002). The study on circumstances of out-of-home advertising in America and developing a measurement index of out-of-home advertising in Japan. Josai international reviews, 8(53)-72).

Taylor, C. \& Franke, G. (2003). Business perceptions of the role billboard in U.S. economy. Journal of advertising research 43(2).15-1611.

Taylor, C. R., Franke, G. R. \& Bang, H. k. 92006). Use of effectiveness of billboards: perspective from selective perception. Theory and retail gravity models. Journal of Advertising 35(4), 21-34.

Taylor, C. R., Franks, G. R. \& Bang, H. K. (2006).Use and effectiveness of billboards perspectives from selective perception theory and retail-gravity models. Journal of Advertising 35(4), 21-34.

Willson, R. T., Baack, D. W. \& Till, B. D. (2015). Creative attention and memory for brands: an outdoor advertising field study. International Journal of Advertising, 34(2), 232-261. 